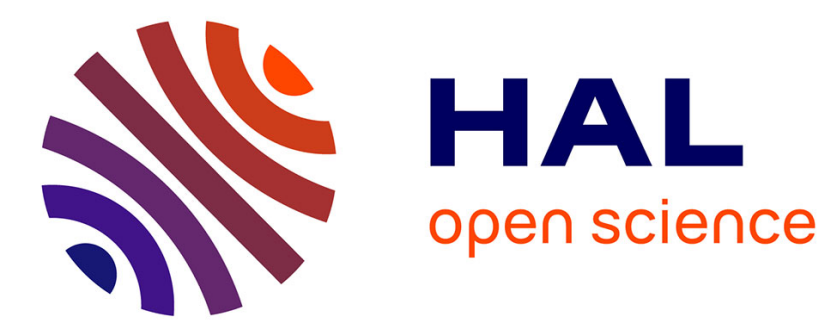

\title{
Clomiphene misuse and risk of severe cardiovascular events
}

Céline Eiden, Véronique Pinzani, Marion Laureau, Nicolas Chapet, Juline Beringer, François Roubille, Mustapha Sebbane, Hélène Peyriere

\section{To cite this version:}

Céline Eiden, Véronique Pinzani, Marion Laureau, Nicolas Chapet, Juline Beringer, et al.. Clomiphene misuse and risk of severe cardiovascular events. European Journal of Clinical Pharmacology, 2020, $10.1007 / \mathrm{s} 00228-020-02858-4$. hal-02512024

\section{HAL Id: hal-02512024 \\ https://hal.science/hal-02512024}

Submitted on 15 Nov 2021

HAL is a multi-disciplinary open access archive for the deposit and dissemination of scientific research documents, whether they are published or not. The documents may come from teaching and research institutions in France or abroad, or from public or private research centers.
L'archive ouverte pluridisciplinaire HAL, est destinée au dépôt et à la diffusion de documents scientifiques de niveau recherche, publiés ou non, émanant des établissements d'enseignement et de recherche français ou étrangers, des laboratoires publics ou privés. 


\title{
Clomiphene misuse and risk of severe cardiovascular events
}

\author{
Céline Eiden ${ }^{1}$ - Véronique Pinzani ${ }^{1}$ • Marion Laureau ${ }^{2} \cdot$ Nicolas Chapet $^{3} \cdot$ Juline Beringer $^{2}$ - François Roubille ${ }^{3,4}$. \\ Mustapha Sebbane $^{2} \cdot$ Hélène Peyrière ${ }^{1}$
}

Dear Editor,

Clomiphene is a selective oestrogen receptor modulator usually used to treat subfertility in women. However, misuse of clomiphene was recently reported in men by bodybuilders, and to treat infertility [1]. Here, we present the case of 2 subjects with severe cardiovascular complications due to clomiphene misuse in a performance-enhancing drug context that occurred in 2019 in a French area.

\section{Case 1}

A 24-year-old man presented at 2:00 p.m. to the emergency unit for tachycardia and palpitations. The patient reported intense strength activity using anabolic-androgenic steroids periodically ( 2 or 3 months ago) for several months and was currently on clomiphene. On admission, the physical examination revealed a heart rate of 108 beats/min and elevated blood pressure of 183/99 $\mathrm{mmHg}$. Cardiac examination revealed a regular rate and rhythm, and electrocardiography revealed sinus tachycardia. Cardiac biomarkers and chest radiography were normal. Troponin value was $5 \mathrm{ng} / \mathrm{ml}$ (normal value $<14$ ) and creatinine-kinase was $330 \mathrm{U} / \mathrm{ml}$. Electrolyte levels and renal function were normal. No other medical

Céline Eiden

c-eiden@chu-montpellier.fr

1 Department of Medical Pharmacology and Toxicology, Montpellier University Hospital, 34295 Montpellier Cedex 5, France

2 Department of Emergency, Montpellier University Hospital, 34295 Montpellier Cedex 5, France

3 Department of Cardiology, Montpellier University Hospital, 34295 Montpellier Cedex 5, France

4 PhyMedExp, University of Montpellier, INSERM U1046, CNRS UMR 9214, 34295 Montpellier Cedex 5, France history was noted. The last clomiphene intake was in the morning at 8 a.m. (one $50-\mathrm{mg}$ tablet). His symptoms improved without treatment a few hours later, and he was discharged at 6:00 p.m. with the recommendation to stop clomiphene use.

\section{Case 2}

A 30-year-old man was hospitalized for acute myocardial infarction (MI) complicated by recovered cardiac arrest. Coronary angiography showed a suspended thrombus into the inter-anterior ventricular with no sign of atheromatous coronary artery disease. A bolus of eptifibatide (Integrelin ${ }^{\circledR}$ ) was administered followed by a thromboaspiration, and a stent was placed. Aspirin, ticagrelor, heparin, and bisoprolol were started. The patient had a history of testosterone injections as doping substances. He recognized tobacco and cannabis smoking (10 pack-year and 3-4 cannabis uses/day). Except for being overweight (body mass index 29.3), no other conventional risk factor for MI was detected in this very young patient. The day before, he had taken 2 pills of $50 \mathrm{mg}$ of clomiphene and one the day of the event. Urine toxicological analyses were positive for cannabinoids, and negative for amphetamines, cocaine, and ethanol. After 1 day in the intensive care unit (ICU), the patient was transferred to cardiac inpatient services. Intracardiac echocardiography showed a left ventricle ejection fraction at $45 \%$. At day 4 , the patient was discharged against medical advice.

Both cases were reported anonymously according to national law to the French medicines regulatory authorities (ANSM) via the Pharmacovigilance and Addictovigilance centres as serious adverse drug reactions resulting from a drug misuse [2]. Clomiphene is misused in male bodybuilders to counteract hypogonadism induced by exogenous testosterone [1]. Clomiphene increases endogenous oestrogens in women and testosterone production levels in men, via an increased release of gonadotropins, which results in a thrombogenic effect. 
A total of 10 other reports of clomiphene misuse by men (median age 30 years old) was collected in the French Pharmacovigilance and Addictovigilance database, 4 in a context of doping, 3 to treat subfertility (2 unknown). Cardiovascular effects reported in 5/10 cases ( 2 tachycardia/palpitation, 1 hypertension, 1 chest pain, and 1 pulmonary embolism). In the worldwide Pharmacovigilance database (VigiBase $\AA$ ), since 2012, 17 other cases have been reported (research criteria: "men" and "cardiac disorder") with a recent increase of reports (4 in 2018, 6 in 2019), with fatal issue in 7 cases (in association with anabolic steroids in 6). In the literature, cases of acute cardiovascular complications after the initiation of clomiphene in the context of ovulatory dysfunction have been reported [3-6], as well as cases of deep venous thrombosis in the context of male hypogonadism and infertility [7].

The use of appearance- and performance-enhancing drugs is increasing and exposes patients to potential life-threatening complications. Clomiphene is usually associated with other drugs to enhance androgen production that could also predispose patients to cardiovascular risk.

\section{References}

1. Ip EJ, Doroudgar S, Lau B, Barnett MJ (2019) Anabolic steroid users' misuse of non-traditional prescription drugs. Res Soc Adm Pharm 15:949-952

2. Jouanjus E, Gibaja V, Kahn JP, Haramburu F, Daveluy A (2015) Signal identification in addictovigilance: the functioning of the French system. Therapie. 70:113-131

3. Abuzeyad FH, Ibnaouf ES, Farras MA (2017) Clomiphene associated inferior STEMI in a young female due to right coronary artery dissection. Case Rep Emerg Med 2017:4747831

4. Avşar Ş, Öz A, Köken Avşar A, Kaya A, Börklü EB (2018) Acute myocardial infarction associated with clomiphene citrate in a young woman. Turk Kardiyol Dern Ars 46:401-405

5. Hardegree EL, Tweet MS, Hayes SN, Gulati R, Kane GC (2012) Multivessel spontaneous coronary artery dissection associated with hormonal infertility therapy in a 39-year-old female. J Cardiol Cases 5(2):e69-e72

6. Duran JR, Raja ML (2007) Myocardial infarction in pregnancy associated with clomiphene citrate for ovulation induction: a case report. J Reprod Med 52:1059-1062

7. Zahid M, Arshad A, Zafar A, Al-Mohannadi D (2016) Intracranial venous thrombosis in a man taking clomiphene citrate. BMJ Case Rep 2016:bcr2016217403. https://doi.org/10.1136/bcr-2016-217403 